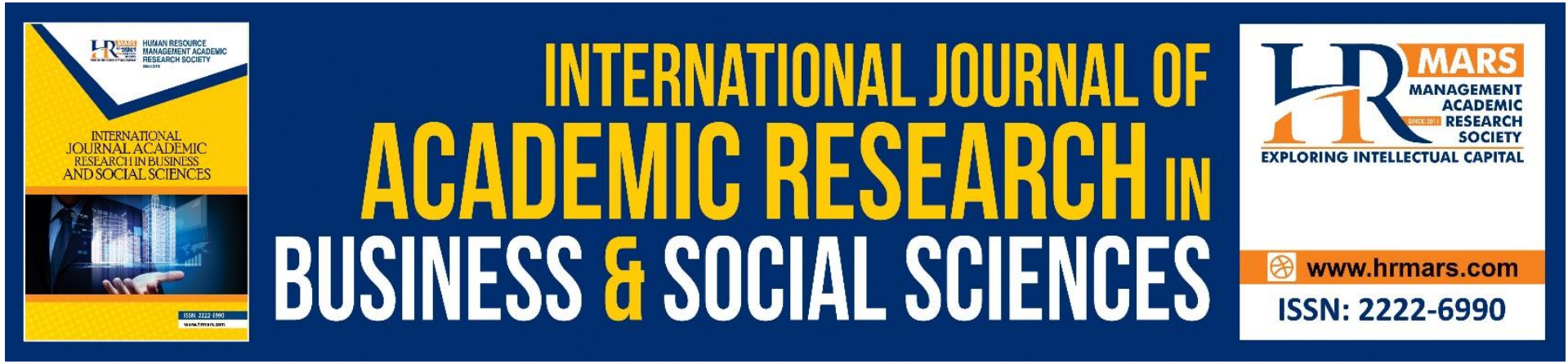

\title{
The Role of Fiqh Method in Strengthening Fatwa Related to Vaccine Injection for Prevent Covid-19 by Perlis State Mufti Department
}

\section{Ahmad Yusairi Yusli, Fathullah Asni \& Amirah Izzati binti Umar}

To Link this Article: http://dx.doi.org/10.6007/IJARBSS/v11-i8/10674

DOI:10.6007/IJARBSS/v11-i8/10674

Received: 10 June 2021, Revised: 13 July 2021, Accepted: 30 July 2021

Published Online: 20 August 2021

In-Text Citation: (Yusli et al., 2021)

To Cite this Article: Yusli, A. Y., Asni, F., \& Umar, A. I. binti. (2021). The Role of Fiqh Method in Strengthening Fatwa Related to Vaccine Injection for Prevent Covid-19 by Perlis State Mufti Department. International Journal of Academic Research in Business and Social Sciences, 11(8), 1439-1449.

Copyright: @ 2021 The Author(s)

Published by Human Resource Management Academic Research Society (www.hrmars.com)

This article is published under the Creative Commons Attribution (CC BY 4.0) license. Anyone may reproduce, distribute, translate and create derivative works of this article (for both commercial and non-commercial purposes), subject to full attribution to the original publication and authors. The full terms of this license may be seen at: http://creativecommons.org/licences/by/4.0/legalcode

Vol. 11, No. 8, 2021, Pg. 1439 - 1449

Full Terms \& Conditions of access and use can be found at http://hrmars.com/index.php/pages/detail/publication-ethics 


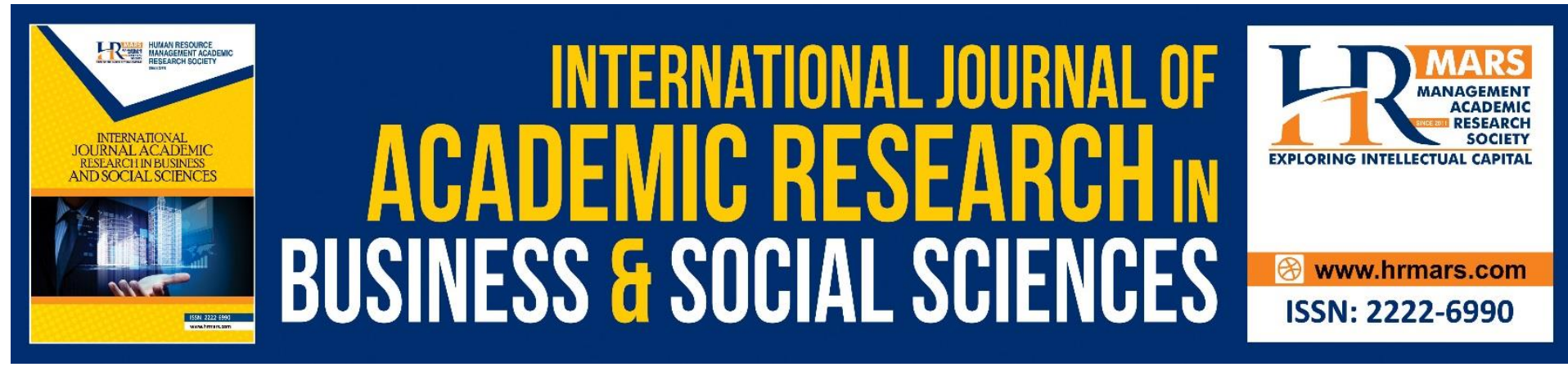

\title{
The Role of Fiqh Method in Strengthening Fatwa Related to Vaccine Injection for Prevent Covid-19 by Perlis State Mufti Department
}

\author{
Ahmad Yusairi Yusli, Fathullah Asni \& Amirah Izzati binti Umar \\ Shariah Department, Faculty of Islamic Studies, Kolej Universiti Islam Perlis (KUIPs) \\ Email:ahmad_yusairi@kuips.edu.my, fathullah@kuips.edu.my, amirahizzati@kuips.edu.my
}

\begin{abstract}
This study examines the role of fiqh methods in strengthening the fatwa related to vaccine injection by the Perlis State Mufti Department. This study is based on the confusion of the Muslim community, especially in the state of Perlis regarding the law (hukm) of vaccination as well as it is a new issue that requires the solution of Shariah through fatwas. Therefore, the Perlis State Mufti Department issued an official fatwa that the Covid-19 vaccine is allowed, and it must (wajib) be taken by the group set by the Government of Malaysia. The methodology of this study is qualitative, where data is obtained through a literature review by referring to books, journals, and relevant circulars. Then the researchers performed a content analysis on the data obtained. The results of the study show that there are four methods of fiqh that support the fatwa issued, namely, (1) harm should be eliminated, (2) should not harm oneself and others, (3) the actions of leaders related to the people should be guided by maslahah and (4) prioritise a matter based on its habit. Therefore, it can be concluded that the fatwa on the adoption of the Covid-19 vaccine issued by the Perlis State Mufti Department is in line and supported by strong figh methods.
\end{abstract}

Keywords: Vaccine, Covid-19, Fatwa, Mufti Perlis Department, Fiqh Method

\section{Introduction}

The development of society and modernisation has contributed to changes in the lifestyle and thinking of the Muslim community, as well as raising various new issues that require a view of Shariah law (Asni, 2020). Competent bodies, especially the Mufti Department, are aware that the Muslim community in Malaysia is increasingly aware of the importance of the role of fatwas in daily life, given the increasing number of questions posed to the Mufti Department from various aspects and areas of life according to Shariah perspective (Asni, 2017).

As informed that Islamic religious affairs in Malaysia are under the responsibility of the State Islamic Religious Council (MAIN) to represent each state (Asni, 2018). While for fatwa matters are under the responsibility of the mufti department, which is one of the departments under MAIN (Asni, 2017). Thus, the mufti department will answer all religious questions and issues among government bodies or the public through the issuance of fatwas (Asni et al., 2021). This concept works for every state, including the state of Perlis. Fatwa is one of the important instruments to help the development of Islamic law. It is constantly 
evolving in line with its nature which is always sensitive to the diversity of problems that occur in society (Asni, 2017). Thus, it can be understood that the development of current life in society will affect various Shariah issues (Asni \& Sulong, 2017).

The COVID-19 pandemic across the country has had a diverse impact, especially on health issues. Therefore, various efforts have been made to prevent the spread of the virus such as vaccines that act as self-immunity. In pharmaceuticals, biotechnology is widely used to produce various types of vaccines as a preventive measure against the epidemic of infectious diseases (Ismail, 2020).

However, there are doubts among the Muslim community about the halal status of the vaccine. Also, at the same time, the status of Shariah law on the need to take the vaccine, whether it is compulsory or optional, is often a question among the Muslim community (Hamid, 2019; Sinar Harian, 2021). While the government strongly encourages the vaccine by the public so that it serves as a group immunity and can curb the spread of Covid-19 among the community. This illustrates that the role of the Perlis State Mufti Department is very important in helping the government curb the spread of the epidemic through fatwas to be used as a reference to the public (Asni \& Sulong, 2016; Muhamad Asni \& Sulong, 2016). Thus, this article will focus on the discussion on the fatwa of the Perlis state mufti department on the law of vaccination and analyse it from the point of view of fiqh method.

\section{The Concept of Figh Method}

The term qawaid fiqhiyyah consists of two words, namely qawaid which is jama' (plural) for qa'idah and fiqhiyyah. In terms of language, qa'idah means al-mabda' (principle) or al-asas (foundation) (Ibn Nujaym, 1999). While fiqhiyyah from the language point of view means understanding. The combination of these two words produces a term of knowledge known as qawaid fiqhiyyah. According to al-Zarqa' (2012), the term qawaid fiqhiyyah is a universal principle of figh in a concise text. It covers laws issued in general and has many branches of fiqh law. While al-Nadwi (1994) states that the term qawaid fiqhiyyah is the universal principle of figh and encompasses the general Shariah laws from various chapters (al-Salam, 1994).

Based on the definitions presented, it can be understood that qawaid fiqhiyyah is a method produced by the mujtahid as a basic reference in understanding fiqh's laws, which covers various chapters. It is one of the fields of knowledge that must be mastered by mufti, especially in understanding the laws of fiqh that develop from time to time. Understanding this knowledge indirectly gives a person malakah al-fiqhiyyah (figh ability) because the source of this knowledge is based on the Qur'an, hadith, the opinions of the companions and the scholars of tabi'in, as well as through the process of ijtihad (Abd Rahman, 2013).

\section{History of The Formation of Qawaid Fiqhiyyah}

From a historical point of view, the knowledge of qawaid fiqhiyyah has gone through three main stages, namely the initial stage, development, and consolidation (al-Nadwi, 1994).

First stage: Beginning

This stage began in the time of the Prophet PBUH which is the time the Shariah was revealed and continued until the 3rd century. At that time, the method of fiqh has not yet been formed into a specific discipline of knowledge, however its practicality can be seen through the hadith of the Prophet, athar from the Companions and the scholars of Tabi'in. For example, the words of the Prophet which means, "cannot harm yourself and cannot harm others (Ibn Majah, 2021)." Although there is still no knowledge of qawaid fiqhiyyah as a discipline of 
knowledge, the society at that time understood that all things that can cause danger, then it is prohibited by Shariah.

Similarly, as Ibn Taimiyyah (2008) discussed on the hadith of the Prophet, which means, "Anything intoxicating whether a little or a lot is forbidden according to Shariah". According to him, the Prophet had gathered with what was bestowed on him through the hadith, namely jawami' al-kalim (a short speech but a concise meaning) that everything that covers the mind and intoxicates is forbidden regardless of the type of ingredient, food, or drink. This shows that the speech of the Prophet basically led to a method that explains a problem more broadly.

Second Stage: Development

This stage began in the 4th century after the method of figh began to be known and gained a special position in one of the debates of the discipline of Shariah. At that time, it had gone through a phase of lack of aspects of ijtihad and society at that time was more inclined to taqlid. This is where the importance of writing and bookkeeping of fiqh problems that have arisen from the previous scholars becomes clear to remain to be used as a source of reference. This century has seen the culture adopting basic theories established by earlier scholars in dealing with current fiqh issues. Therefore, many writings were born in the field of qawaid fiqhiyyah which is seen as so important in the science of fiqh (al-Nadwi, 1994).

The first writing in the field of qawaid fiqhiyyah was started by the scholars of the Hanafi school, namely Abu Tahir al-Dabbas. Among his services in qawaid fiqhiyyah is that he has compiled 17 important methods in the Hanafi school. Then al-Karkhi developed the methods into 37 methods through his work usul al-karkhi. Then came the writing of the Maliki school, namely the usul al-futya by al-Khushani (al-Nadwi, 1994).

Next in the 5th century, Abu Zaid al-Dabusi produced the book Ta'sis al-Nadzar. Next in the 6th century, the book idhah al-qawaid was written by 'Alauddin al-Samarqandi. The 7th century has seen the growth of numerous writings in this field from various sects. Among them are the book qawaid al-ahkam fi masalih al-anam by 'Izzuddin Abd al-Salam from the Shafi'i school and the book al-mudhhab fi dhabt qawaid al-madhhab by Muhammad bin alBakri from the Maliki school.

Then in the 8th century, the publication of many books that discuss the science of qawaid fiqhiyyah. Among them are the book of al-ashbah wa al-nadza'ir by Tajuddin Al-Subki, the book of al-ashbah wa al-nadza'ir by al-Isnawi, the book of al-manstsur by Badruddin alZarkashi and the book of al-qawaid fi al- fiqh by lbn Rajab al-Hanbali. In the 9th century, the science of qawaid was getting closer to the peak of its glory in writing when so many books appeared. Among them are the book of al-qawaid by Ibn al-Mulqin, asna al-maqasid fi tahrir al-qawaid by al-Zubayri, the book of al-qawaid al-mandzumah by Ibn al-Ha'im al-Maqdisi, the book of al-qawaid by Taqiyyuddin al-Hisni, the book nudhm al-zhakha'ir fi al-ashbah wa alnadza'ir by Abdul Rahman bin Ali al-Maqdisi and the book al-qawaid wa al-dhawabith by Ibn Abdul Hadi (al-Nadwi, 1994).

Finally, in the 10th century, the knowledge of qawaid fiqhiyyah became more widespread and almost to the point of completion when there were many references from the 4th century to the 10th century. The books of this century are the result of studies and methods that have been compiled by previous scholars and then perfected. Among the books are al-ashbah wa al-nadza'ir by Jalaluddin al-Suyuti, Ibn Nujaim al-Hanafi and Abu al-Hasan al-Zaqqaq al-Tujibi al-Maliki (al-Nadwi, 1994).

In conclusion, this second stage is the golden stage for the glory of qawaid fiqhiyyah when the existence of competition and hard work by the scholars of various sects to develop 
the knowledge. This gives an advantage to the next generation to refer and improve the knowledge of qawaid fiqhiyyah.

Third stage: Consolidation

This stage began in the 11th century. It was during this period that the book of majallah alahkam al-'adliyyah was produced. Basically, the book has 99 phases and each of these phases will discuss the qawaid fiqhiyyah. An example of the method found in the book is not denying the occurrence of changes in the law (hukm) due to changes in time (al-Nadwi, 1994). Majallah Al-Ahkam Al-'Adliyyah Al-'Uthmaniyyah was first codified in $1292 \mathrm{H}$. The debate presented by this book is more inclined to the Hanafi school. This book was widely adopted as a legal reference by the Ottoman government for 50 years (al-Nadwi, 1994).

\section{Qawaid Fiqhiyyah Al-Kubra}

Qawaid fiqhiyyah al-kubra is also known as qawaid asasiyyah. Basically, it has five basic branches, and its users are agreed upon in the discipline of Shariah. These five methods form various branches of methods that include the field of worship and muamalat (al-Zuhaili, 2013). The five basic methods are:

1) Each affair is based on its purpose.

2) Confidence cannot be removed by doubt.

3) Difficulty bringing convenience.

4) Harm must be eliminated.

5) Custom is used as a source of law.

\section{Fatwa Reference in the Perlis State Mufti Department}

In general, in issuing a fatwa, it is necessary to go through the science of usul fiqh. Usul al-figh is the main essence in the method of fatwa which is the main pre-condition for the qualification of a mufti (Asni \& Sulong, 2017). A fatwa is a view or decision, either personal or produced by a group of mujtahids on a particular Shariah law. The accuracy of a fatwa is highly dependent on the method of evidence used and its parallel with the maqasid al-shariah. According to al-Ghazali (1997) and al-Shaukani (1999), a mufti is a mujtahid, a person who can perform ijtihad and infer the law.

Thus, mufti and mujtahid are the same in general, only different in terms of the cause that is a fatwa issued to answer a question or a problem that has occurred, while ijtihad is not bound by such conditions (al-Qaradawi, 2011). Nevertheless, the mufti can proactively address a question by directing specific legal research even if there is no application for a fatwa as a preparatory measure (Khudzri, 2006). Based on this, some scholars do not differentiate between the functions of mufti and mujtahid because each can issue a law whether because of the existence of questions or not (al-Shatibi, 1997).

While the meaning of ijtihad, al-Shaukani (1999) defines it as mobilising the ability to issue comprehensive Shariah law by following accurate inferences. While al-Amidi (2003) defines ijtihad as pouring all the ability to understand Shariah law which is speculative or uncertain (zanni), he feels unable to find more than that. Based on this, al-Ghazali makes the limitation of all abilities as part of the definition of al-ijtihad al-tam (perfect ijtihad) (Asni \& Sulong, 2017). Thus, ijtihad can be understood as the effort of a mujtahid who maximises all his mental and intellectual efforts to study and understand Shariah law. It is an effort that ultimately produces findings or results from such ijtihad, called a fatwa. Thus, fatwa is a result of ijtihad (Asni \& Sulong, 2017). 
In Malaysia, the fatwa issuance process is through a reference that has been set by the Administration of Islamic Religious Affairs Enactment for each state. Through the provision, every state in Malaysia except Perlis, the law provides that the priority to refer is to the Shafi'i school which is based on the provisions of qawl muktamad (Asni \& Sulong, 2017). Similarly provided in the relevant statutes as in the Kedah State Mufti and Fatwa Enactment 2008, Section 26 provides that in considering any fatwa under Section 21 or recommending any opinion under Section 25, the Fatwa Committee shall, generally following Shafi'i school based on al-Quran, hadith, ijma' and qiyas.

Unless the Fatwa Committee believes that by following the qawl muktamad of the Shafi'i school, a situation contrary to the public interest will result, then the Fatwa Committee may follow the qawl muktamad of the Hanafi, Maliki or Hanbali schools after obtaining the consent of His Majesty the Sultan. Similarly, suppose the Fatwa Committee is opined that none of the qawl muktamad of the four sects can be followed without leading to a situation contrary to the public interest. In that case, the fatwa may be decided at its discretion without being bound by the qawl muktamad of any of the four sects.

While in the State of Perlis, control over fatwa references is not made based on narrow sects but on the public interest or current maslahah. This ensures that the fatwa reached is more accurate (rajih) by maintaining the two main sources, namely al-Quran and al-Sunnah in finding views that meet the maslahah within the scope of the views of the sects recognised by ahl al-Sunnah wa al-Jama'ah (Asni \& Sulong, 2017). In this regard, Section 7, Perlis Islamic Religious Administration Law Enactment 1964 provides:

(4) The Majlis when issuing a Fetua and then Shara'iah Committee when giving its opinion under sub-section (2) shall follow the Al-Quran and or Sunnah Rasulal Allah Sallal Allah 'Allaihi Wasallam. Provided that where the following of such tenets would be opposed to the public interest.

The Perlis fatwa reference approach implies that the decision of a fatwa must look at the changing public interest according to the current situation and the core reference to Shariah propositions (Asni \& Sulong, 2017). When this relationship is built, then an accurate fatwa (rajih) decision will be achieved. Based on the study of Omar and Hussin (2018), although fatwa references made by mufti departments are more inclined to sectarian references, mufti departments also refer to fiqh methods as supporting in strengthening fatwas.

\section{Methodology}

The methodology of this study is qualitative, where the data is obtained through a literature review by referring to books, journals, official websites, and related circulars. Then the researchers conducted a content analysis of the data obtained to see the role of fiqh methods in strengthening the fatwa related to vaccine injection by the Perlis state mufti department.

\section{Results and Discussion}

\section{fatwa decision}

Based on the result of the discussion in the Perlis State Fatwa Committee meeting which convened on 22 February 2021, the Fatwa Committee Members have decided that, "The use of COVID-19 Vaccine is allowed and it must (wajib) be taken by the group designated by the Government of Malaysia (Perlis State Mufi Department, 2021)". Based on the fatwa, the Perlis State Mufti Department has stated the compulsory on vaccination by most of the community in Malaysia. This is because the federal government stipulates that $80 \%$ of the Malaysian 
population must take the vaccine to create cluster immunity (Covid-19/Ministry of Health Malaysia, 2021). The decision of the fatwa is in line with the four methods of fiqh that can help strengthen the fatwa issued. Among the methods of fiqh are;

The first method of fiqh: Harm must be eliminated

This method of fiqh is formed from the analysis of a combination of several verses of the Qur'an that command to reject and avoid harm. Among them is the Word of Allah SWT which means, "And spend of your substance in the cause of Allah, and make not your own hands contribute to (your) destruction; but do good; for Allah loveth those who do good. (alBaqarah: 195)." This method means that all the harm that comes, then it is obligatory to be eliminated regardless of whether it has happened, is happening, or will happen, it is obligatory to be prevented (al-Zarqa', 2012).

Based on the current situation, the threat that worries all parties is the danger of the Covid-19 virus. The virus can penetrate a person's body and can lead to death. According to current data, the number of Covid-19 cases in Malaysia is over one million cases which is a very large number. While the number of deaths due to Covid-19 is close to 10 thousand people (Covid-19/Ministry of Health Malaysia, 2021). According to the Director of Health Malaysia, variants such as Delta can be transmitted among close contacts in a very short time, which requires only five seconds. Therefore, the vaccine is seen to be able to provide a positive effect on efforts to curb the spread of this epidemic, and it should be taken into consideration by all parties so that this existing harm can be eliminated as soon as possible (Covid-19/Ministry of Health Malaysia, 2021). Thus, the obligation in vaccination is appropriate because of the great risk of harm that needs to be eliminated.

The second method of fiqh: Must not harm oneself and others

This method is based on the Prophet PBUH's hadith that can not harm oneself and others (Ibn Majah, 2001). Al-Shabshiri (1998) explained that the meaning of the word al-dharar in the hadith is something that benefits oneself, but it harms others. The word al-dhirar also means something that does not benefit oneself, in fact it also harms the people around.

This method coincides with the goal of vaccination, which is a preventive measure for oneself and society. A person whose body is not protected by the immune system can pose more risks and harmful effects on oneself, becoming a carrier of the virus to those around him as the virus spreads rapidly. This is different for someone who has taken the vaccine. It can minimise the virus's susceptibility and reduce the harmful effects when faced with this Covid-19 epidemic (Covid-19/Ministry of Health Malaysia, 2021).

The third method of figh: The actions of leaders related to the people should be guided by maslahah

According to al-Zuhaili (2013), what is meant by a leader in this method is any leader who leads human affairs in general, such as a government leader. Moreover, Zaidan (2001) stated that the government has the right to give instructions to the people where it is believed to bring maslahah, while the people are obliged to abide by it. Thus, in the Covid-19 pandemic situation, there were various initiatives from the government in curbing the spread of this epidemic. Among the things implemented are enforcing the tightened Movement Control Order (MCO) in some areas with high cases and cross-state prohibition laws (Covid19/Ministry of Health Malaysia, 2021). This coincides with the hadith of the Prophet PBUH, "when you hear a contagious epidemic in a country, do not come to that country, if the epidemic is contagious in the country where you are, then do not leave the country because you want to flee (Muslim, 2006). 
Similarly, physical incarceration instructions, performing prayers at a distance, wearing face masks, and quarantine, all of these things are essential in the process of avoiding the spread of the Covid-19 epidemic. A person who willfully violates these instructions is deemed to have committed an offence. This is because Shariah has given authority to leaders to set decisions on issues involving public good and harm. This is based on the hadith of the Prophet, "it is obligatory to listen and obey the leader to every Muslim on the things he likes and he hates, as long as he is not commanded to commit immorality, when he is commanded to commit immorality, then no more listening and obedient (Al-Bukhari, 1997)."

Apart from that, one of the government's directives that must be complied with so that Malaysians are free from the dangers of this epidemic is to take vaccinations. Beginning November 22, 2020, the Malaysian Minister of Health has entered into a preliminary agreement with the COVAX facility to obtain a vaccine that will cover $10 \%$ of Malaysians. Subsequently, on 24 November 2020, the Malaysian Minister of Health once again signed an agreement for the initial purchase of 12.8 million doses of Pfizer vaccine to accommodate $20 \%$ of Malaysians. These efforts continue to increase from time to time to ensure the immunisation needs of Malaysians as a whole (Minister in the Prime Minister's Department of Religious Affairs, 2020).

Therefore, it is the duty of those required by the government to take the vaccine to take the injection. The refusal not to take the vaccine is not only self-harming but will also cause inconvenience to many parties, including the front-line personnel when they have to exert all their energy in curbing the epidemic.

The fourth method of fiqh: Prioritise a matter based on its habit, compared to a rare thing Many laws of fiqh result from this method. For example, a woman who does not know when her menstruation is interrupted either in normal time or uncertain time should take six or seven days because that is the normal menstrual period for many women (al-Zuhaili, 2013). As for the relationship between this method of fiqh and the injection of the vaccine, it is customary for the injection of this vaccine to provide benefits and good effects on the human body. This has been tested and proven through many studies conducted by trusted medical bodies.

This is as emphasised by the Majma' Fuqaha' al-Shari'ah in America that is concerning the issue of vaccine injections, the Majma' obtained views from Muslim doctors who believe that the injections have gone through and have been accepted by medical bodies that performed more than 40,000 people, where there were no adverse symptoms or side effects within two months (Minister in the Prime Minister's Department of Religious Affairs, 2020).

Similarly, various vaccines have long been used on the human body to prevent various dangerous diseases. Among them are Menveo Meningitis Vaccine, Human Papilloma Virus Vaccine, Measles, Tuberculosis, Cough and Whooping Vaccine (Minister in the Prime Minister's Department of Religious Affairs, 2020). Therefore, the use of vaccines is not harmful to humans because considering the common factors that occur in the injection is more beneficial than harmful. 
Graph 1: Strengthening of figh methods in the fatwa related to a vaccine injection

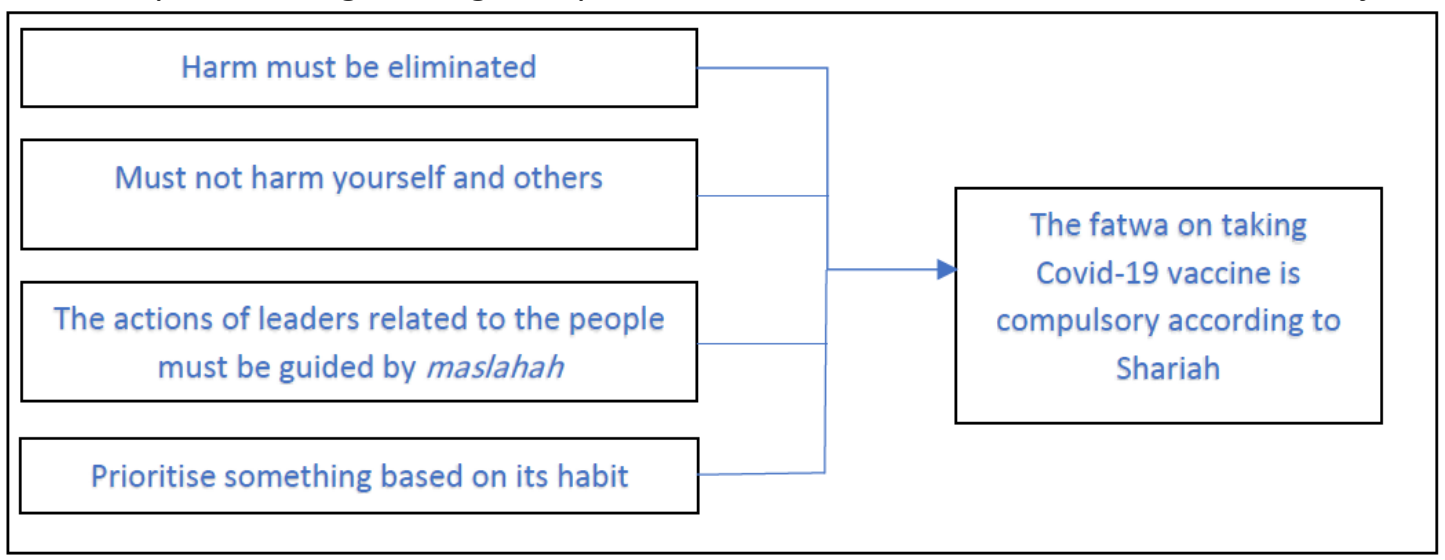

Thus, the results of this study greatly impact the strengthening of the fatwa related to vaccination by the Perlis state mufti department, where four methods of fiqh support this fatwa. In addition, the results of this study help strengthen the public's trust to take vaccinations and are in line with Shariah requirements.

\section{Conclusion}

This study examines the figh method approach in strengthening the fatwa related to vaccine injection by the Perlis State Mufti Department. This study is based on the confusion of the Muslim community, especially in the State of Perlis regarding the law of vaccination as well as it is a new issue that needs to be resolved from Shariah point of view. Therefore, the Perlis State Mufti Department issued a fatwa that the intake of the Covid-19 vaccine is allowed, and it must (wajib) be taken by the group designated by the Government of Malaysia.

The results of the study show that there are four methods of figh that support the fatwa issued, namely, (1) harm should be eliminated, (2) should not harm oneself and others, (3) the actions of leaders related to the people should be guided by maslahah and (4) prioritise something based on its habit, over rare things. Therefore, it can be concluded that the fatwa on the adoption of the Covid-19 vaccine issued by the Perlis State Mufti Department is in line with fiqh methods.

\section{Acknowledgment}

Kolej Universiti Islam Perlis sponsored this study under a short-term research grant (STG), no: STG-011 KUIPs/RMIC/200/STG-011 (28).

\section{References}

Abd Rahman, N. S. (2013). Pengenalan Ilmu Qawaid Fiqhiyyah. Kuala Lumpur: Open University Malaysia.

Al-Amidi, S. M. (2003). Muntaha al-Sul fi 'Ilm al-Usul. Beirut: Dar al-Kutub al-'Ilmiyyah

Al-Bukhari, M. I. (1997). Sahih al-Bukhari. Beirut: Dar Ibn Katsir.

Al-Ghazali, M. M. (1997). al-Mustasfa fi 'Ilm al-Usul. Beirut: Muassasah al-Risalah

Al-Nadwi, A. A. (1994). Al-Qawaid al-Fiqhiyyah. Damshiq: Dar al-Qalam.

Al-Qaradawi, Y. (2011). Madkhal li Dirasah al-Shari'ah al-Islamiyyah. Qaherah: Maktabah Wahbah

Al-Salam, I. A. (1994). Qawaid al-Ahkam. Qaherah: Maktabah Al-Kulliyyat alAzhariyyah.

Al-Shabshiri, M. A. (1998), Al-Jawahir al-Bahiyyah. Riyad: Maktabah Nizar Mustafa al-Baz. 
Al-Shatibi, I. M. (1997). al-Muwafaqat. Sa'udi: Dar Ibn 'Affan

Al-Shaukani, M. A. (1999). Irshad al-Fuhul ila Tahqiq al-Haq min 'Ilm al-Usul. Beirut: Dar alKitab al-'Arabi

Al-Zarqa', A. M. (2012). Sharh Al-Qawaid Al-Fiqhiyyah. Damshiq: Dar al-Qalam.

Al-Zuhaili, M. M. (2013). al-Qawaid al-Fiqhiyyah wa Tathbiqatuha fi Al-Madhahib Al-Arba'ah. Dimashq: Dar al-Fikr.

Asni, F. (2018). Analysis of the Concept of Fatwa Uniformity according Mura'ah Al-Khilaf Method. International Journal of Academic Research in Business and Social Sciences, 8(7).

Asni, F. (2020). Management of fatwa standardisation on the practice of bay' inah contract in Malaysia: an analysis according to usul al-Figh and mura'aht al-Khilaf method. Qualitative Research in Financial Markets.

Asni, F. A. H. M. (2017). Al-Syatibi Approach in Fatwa Standardizations and its Effect of States' Fatwa Committee. International Journal of Academic Research in Business and Social Sciences, 7(4), 1175-1183.

Asni, F. A. H. M. (2017). Pengamalan Hadis Daif Dalam Pengeluaran Hukum Syarak Menurut Perspektif Ilmu Hadis Dan Penggubal Fatwa Di Malaysia. Al-Qanatir: International Journal of Islamic Studies, 7(1), 1-9.

Asni, F. A. H. M. (2017). The Practices Of Weak (Daif) Hadiths In Production Of Islamic Law From The Perspectives Of Hadith Studies And Fatwa Legislators In Malaysia. AlQanatir: International Journal of Islamic Studies, 7(1), 1-9.

Asni, F. A. H. M., Sulong, J., \& Ismail, A. (2017). Penggunaan hadis daif dalam fatwa mengenai wasiat di Malaysia serta langkah penyelesaiannya. Journal of Hadith Studies, 2(1): 3950

Asni, F., \& Sulong, J. (2021). The mura'ah al-khilaf and ma'alat method in fatwa decisions: its application for fatwa coordination related to conditional hibah in Malaysia. International Journal of Islamic and Middle Eastern Finance and Management.

Asni, M. F. A. H. M., \& Sulong, J. (2016). Fatwa berhubung wasiat wajibah dan keseragaman peruntukannya dalam fatwa Negeri-Negeri Di Malaysia. Al-Qanatir International Journal of Islamic Studies, 5(1), 1-15.

Asni, M. F. A. H. M., \& Sulong, J. (2017). Fatwa Coordination between States: Analysis Of The Practices Of Standardization And Its Method In Malaysia. Journal of Fatwa Management and Research, 9(1), 86-109.

Asni, M. F. A. H. M., \& Sulong, J. (2017). Penyelarasan Fatwa Antara Negeri-Negeri: Analisis Amalan dan Kaedah Penyeragamannya di Malaysia. Nilai: Universiti Sains Islam Malaysia

Asni, M. F. A. H. M., \& Sulong, J. (2017). Penyeragaman Fatwa Berhubung Isu-Isu Wakaf di Malaysia: Satu Sorotan Awal: Standardisation of Fatwa Regarding Waqf Issues in Malaysia: A Literature Review. Journal of Fatwa Management and Research, 9(1), $110-$ 128.

Covid-19/Kemeterian Kesihaatan Malaysia. (2021). Terkini Harian. See: https://covid19.moh.gov.my/ (Assessed on 5/8/2021).

Hamid, S. A. (2019). ANTI VAKSIN: APAKAH NATIJAHNYA KEPADA MASYARAKAT?. eBangi, 16(2).

Ibn Majah, M. Y. (2001). Sunan Ibn Majah. Riyadh: Dar al-Salam.

Ibn Nujaym. (1999). Al-Ashbah Wa al-Nadha'ir. Beirut: Dar al-Kutub 'Ilmiyyah. 
Ibn Taimiyyah, A. A. (2008). Majmu' al-Fatawa. Riyad: al-Auqaf al-Sa'udiyyah.

Ismail, A. M. (2020). Fatwa Sebagai Mekanisme Pencegahan Penularan Pandemik Covid-19: Fatwa as Preventive Mechanism of Containing the Spread of Covid-19 Pandemic. Journal of Fatwa Management and Research, 14-25.

Perlis State Mufti Department. (2021). Fatwa Vaksin COVID-19. See: https://muftiperlis.gov.my/index.php/himpunan-fatwa-negeri/456-fatwa-vaksincovid-19 (Assessed on 5/8/2021).

Khudzri, W. A. R. (2006). Analisis Penggunaan Kaedah Istinbat Dalam Penetapan Fatwa Di Malaysia: Kajian Di Jabatan-Jabatan Mufti Terpilih. PhD Dissertation, Department of Islamic Studies, School of Humanities, USM.

Minister in the Prime Minister's Department of Religious Affairs. (2020). Al-Bayan, Bil.7. Published by Office of the Minister in the Prime Minister's Department of Religious Affairs.

Metro. (2021). Vaksin: Setahun untuk negara capai imuniti kelompok. See: https://www.hmetro.com.my/utama/2021/02/672533/vaksin-setahun-untuknegara-capai-imuniti-kelompok (Assessed on 5/8/2021).

Asni, M. F. A. H., \& Sulong, J. (2016). Fatwa concerning Qabd in Hibah and the insertion of Qabd element in States Fatwa in Malaysia. Journal of Islamic Studies and Culture, 4(1), 143-154.

Muslim, H. (2006). Sahih Muslim. Riyad: Dar Thibah.

Omar, S. N. A. C., \& Hussin, M. N. M. (2018). Pemakaian Kaedah-Kaedah Fekah Dalam Institusi Fatwa Di Wilayah Persekutuan Dari Tahun 2010-2014. Online Journal of Research in Islamic Studies, 5(3), 37-64.

Harian, S. (2021). Khutbah perjelas kekeliruan vaksin Covid-19 See: https://www.sinarharian.com.my/article/125885/EDISI/Khutbah-perjelas-kekeliruanvaksin-Covid-19 (Assessed at 5/8/2021).

Zaidan, A. (2001). Al-Wajiz fi Sharh al-Qawaid al-Fiqhiyyah. Beirut: Muassasah al-Risalah. 